\title{
Response of Inland Coastal Villages to Coastal Erosion
}

\author{
Swapan Kumar Tala
}

M. A., M. Phil., UGC NET

\begin{abstract}
India has a vast stretch of coastline of about 4670.84 miles (7516.99kms.) of which 3370 miles (5423.489kms.) borders along the mainland and 1301 miles (2093.75kms.) along the islands of Andaman and Nicobar and Lakshadweep. About 30\% of the country's population lives within $60 \mathrm{~km}$ of the coastline. Many interactive processes are happening within the coastal zones which are directly and indirectly the coastal population. These processes are erosion, accretion and transport of sediments which normally occur due to natural processes, anthropogenic activities and episodic events like storm, cyclones, surges and coastal floods. These processes contribute to the coastal morphological changes which affect the alignment of the shoreline, beaches, etc. The east coast is subject to some of the most severe storm surges in the world. Every year the depression formed in the Bay of Bengal move towards the land and strikes the coast.
\end{abstract}

Keywords: Coastal erosion, Cyclone, Sea level change, Degradation

\section{Introduction}

Coastal Zone is transition area between land and water which terrestrial environments influence marine environments and vice-versa (Carter, 1989). Coastal zone is the dynamic junction of ocean, atmosphere andland, undergoes continuous geomorphological changes in response to naturalforces and man-made activities (Komer 1976; Bruun 1962; Horikawa 1978). Natural processes like wind generated waves, tides, currents and continental drifts are always at work and induce major geodynamic changes over a period of time (Raveendra, 2000). Coastal zones almost everywhere have always been densely populated and are nucleus for urbanization, industrial growth and intense agricultural activities. It frequently tends to change from its original environment due to natural or man-made activities.

The Contai coastal belt is extended from Hugli river mouth to the Subarnarekha delta. It is associated with various beach ridges, sand dunes and intervening tidal flats between Rasulpur and Subarnarekha river system. The entire lowland tract is lying between the heights ranging from 2-3 $\mathrm{m}$ above mean sea level (MSL). There are two types of coastal plains, one is younger (close part of the shore) and another is older coastal plain (far part of the shore). There are four sets of beach ridges and sand dunes around Ramnagar, Paniparul and Contai areas in older plain.

Contai coastal belt is a younger coastal area which is basically facing the natural calamities in every year that badly affect their Socio-economic conditions. The most critical natural phenomenon of the Contai coastal belt is coastal erosion. The survey was conducted for a period of one year from $1^{\text {st }}$ June (2019) to $31^{\text {st }}$ May (2020).

\section{Objectives}

1) To study the causes and effects of coastal erosion.

2) To study the current livelihood pattern of the local communities and livelihood adaptation in relation to coastal erosion.
3) Suggest remedial measures for erosion control for this coastal zone.

\section{Methodology}

1) Contai coastal area of Purba Medinipur has been selected for the present study.

2) A sample opinion survey was conducted by interviewing randomly selected coastal hamlets of the Contai coastal belt in order to ascertain the local peoples' response to the coastal erosion they are facing.

\section{Collection of data}

The data for this study have been obtained mainly from primary sources collected through an extensive field survey. Some data have also been collected from secondary sources.

1) Primary Data:-

The primary data has been collected through the survey scheduled.

\section{2) Secondary Data:}

The secondary data i.e., various maps of our study area were collected from DSDA (Digha-Sankarpur Development Authority), NATMO, Survey Of India, Internet etc.

\section{Study Area}

Contai coastal belt is located in West Bengal and Odisha. Its large portion is located in Purba Medinipur District, West Bengal and rest portion is located in Balasore District, Odisha. The northern limit of the coastal tract is demarcated by Orissa coast canal and Hijili tidal canal and southern limit of the coastal tract is Bay of Bengal (A. Paul, 2002). It extends from the mouth of Rasalpurriver to mouth of Subarnarekha river. Total length of Contai (Kanthi) belt is about $45 \mathrm{Km}$. Contai coastal belt is divided into six different sectors according to breaking point by rivers. These are as follows: Junput coastal sector, Soula coastal sector, Mandermoni coastal sector, Sankarpur coastal sector, Digha coastal sector and Talsari coastal sector. 
Contai coastal belt is covered in Topo-Sheet Map No. 73 O/6, $73 \mathrm{O} / 10,73 \mathrm{O} / 13$ and $73 \mathrm{O} / 14$ of Survey of India. Latitudinal extension for the study area is $21^{\circ} 47^{\prime} 20.93^{\prime \prime} \mathrm{N}$ to $21^{\circ} 34^{\prime} 00.67^{\prime \prime} \mathrm{N}$ and longitudinal extension $87^{\circ} 53^{\prime} 29.16^{\prime \prime} \mathrm{E}$ to $87^{\circ} 24^{\prime} 23.74^{\prime \prime} \mathrm{E}$.

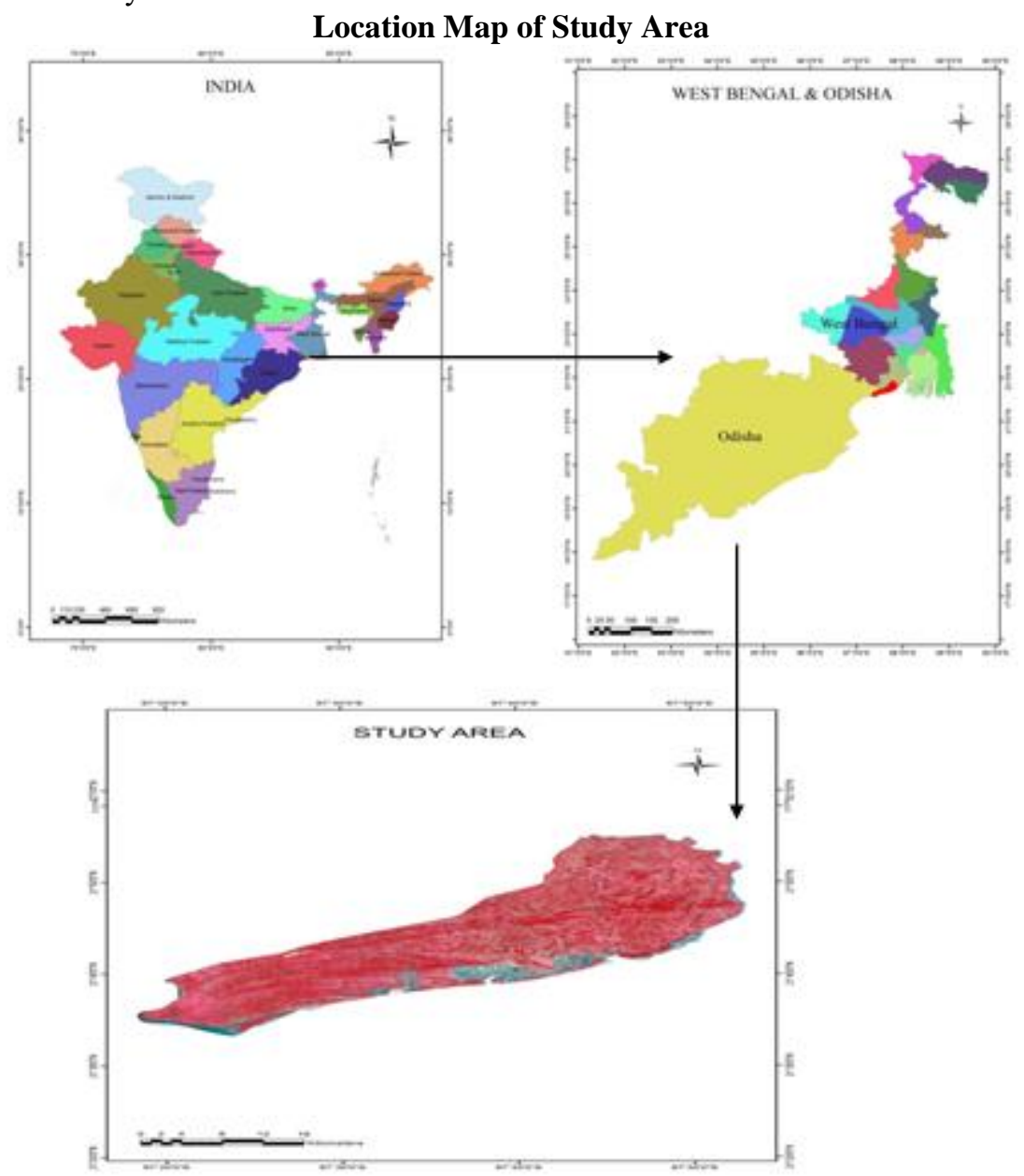

Figure 1: Lacation map of study area

\section{Concept of coastal erosion}

It is noteworthy that based on tidal amplitude, West Bengal coast can be sub-divided into two different coastal environments. These are-

1) The Macro-tidal (tidal range $>4 \mathrm{~m}$ )-Hugli Estuarine plain.

2) Meso-tidal (tidal range 2-4 m)-Medinipur Coast.

$>$ Contai coast low laying, meso-tidal tropical coast.

$>$ On the basis of erosion accretion the entire coast can be divided into two parts (Chakraborty, 1990) -

1. Digha to western portion of Dadanpatrabar - Erosional regime.

2. Eastern portion of Dadanpatrabar to Rasulpur Accretional regime.

The most critical natural phenomenon of the Contai coastal belt is coastal erosion. Beaches, dunes, marshes, mangrove swamps, and barrier bars or islands act as natural physical barriers against storm damage along the lowland coastal plain. Shoreline development of Contai coast has intensified coastal erosion, altered the hydrology of sand dunes and wetlands, and also disrupted natural processes. The protective structure along the shoreline of Contai coast typically built to dissipate the energy of storm waves in turn, disrupt the natural process of sand replenishment, and lead to further erosion in the nearby unprotected areas. The beaches backed by sand dunes are now eroding at a rate of over $12 \mathrm{~cm}$ per year (Paul, 2002). This coastal area has been experiencing several erosion issues due to natural and manmade activities.

According to field surveys, during powerful cyclonic storms and high kotals (High spring tide) the wave of sea water rises above $5.50 \mathrm{~m}$. resulting into formation of vertical slips due to sea erosion, rain cuts with erosion throughout its length from old Digha to Digha Mohana ( $3 \mathrm{~km}$.), Sea dyke from Shankarpur to Tajpur $(3.7 \mathrm{~km}$.) in Ramnagar and Digha PS and sea dyke from Dadanpatrabarh to Bankshal Ghat $(5 \mathrm{~km}$.) in Contai and Junput Coatal PS.

Table 01: Erosion prone area of Contai coastal belt

\begin{tabular}{|c|c|c|c|}
\hline $\begin{array}{c}\text { Sl. } \\
\text { No. }\end{array}$ & $\begin{array}{c}\text { Name of the } \\
\text { P.S. }\end{array}$ & Location & $\begin{array}{c}\text { Most Affected } \\
\text { Length }(\mathrm{km} .)\end{array}$ \\
\hline 1 & $\begin{array}{c}\text { Contai and } \\
\text { Junput Coast }\end{array}$ & $\begin{array}{c}\text { Sea dyke from Dadanpatrabarh } \\
\text { to Bankshal Ghat }\end{array}$ & $5 \mathrm{~km}$. \\
\hline & Ramnagar \\
\cline { 3 - 4 } 2 & $\begin{array}{c}\text { Sea dyke from Old Digha to } \\
\text { and Digha Mohana }\end{array}$ & $3 \mathrm{~km}$. \\
\cline { 3 - 4 } & $\begin{array}{c}\text { Sea dyke from Shankarpur to } \\
\text { Tajpur }\end{array}$ & $3.7 \mathrm{~km}$. \\
\hline
\end{tabular}

Source: Paul A, Coastal Environment, 2002. 


\section{Finding}

\subsection{Causes of coastal erosion}

During our field survey it was asked 'is there coastal erosion in their locality?' Around 52\% have reported that there is a problem of coastal erosion.

Table 2: Response on coastal erosion

\begin{tabular}{|c|c|c|}
\hline Response & No. of Households & Percent (\%) \\
\hline Yes & 44 & 51.76 \\
\hline Total & 85 & 100 \\
\hline
\end{tabular}

I have asked some respondents who have answered positively about the reason of the coastal erosion. They have given various answers to my questions. From their information I have divided the causes into two categories. These are natural and anthropogenic causes. According to them, cyclone $(27.27 \%)$, wave activity $(18.18 \%)$, sea level changes (18.18\%), deforestation (13.64\%), engineering structure $(11.36 \%)$ and others $(6.82 \%)$ are responsible for coastal erosion. Also some respondents have denied to make any comment $(4.55 \%)$.

Table 3: Causes of coastal erosion

\begin{tabular}{|c|c|c|c|}
\hline $\begin{array}{c}\text { Main types of } \\
\text { Coastal Erosion }\end{array}$ & $\begin{array}{c}\text { Sub-types of } \\
\text { Coastal Erosion }\end{array}$ & $\begin{array}{c}\text { No. of } \\
\text { Respondent }\end{array}$ & $\begin{array}{c}\text { Percent } \\
(\%)\end{array}$ \\
\hline \multirow{3}{*}{ Natural } & Tide/Wave activity & 08 & 18.18 \\
\cline { 2 - 4 } & Cyclone & 12 & 27.27 \\
\cline { 2 - 4 } & Sea level change & 08 & 18.18 \\
\hline \multirow{3}{*}{ Human } & Deforestation & 06 & 13.64 \\
\cline { 2 - 4 } & Engineering Structure & 05 & 11.36 \\
\cline { 2 - 4 } & others & 03 & 06.82 \\
\hline & No comments & 02 & 04.55 \\
\cline { 2 - 4 } & Total & 44 & 100.00 \\
\hline
\end{tabular}

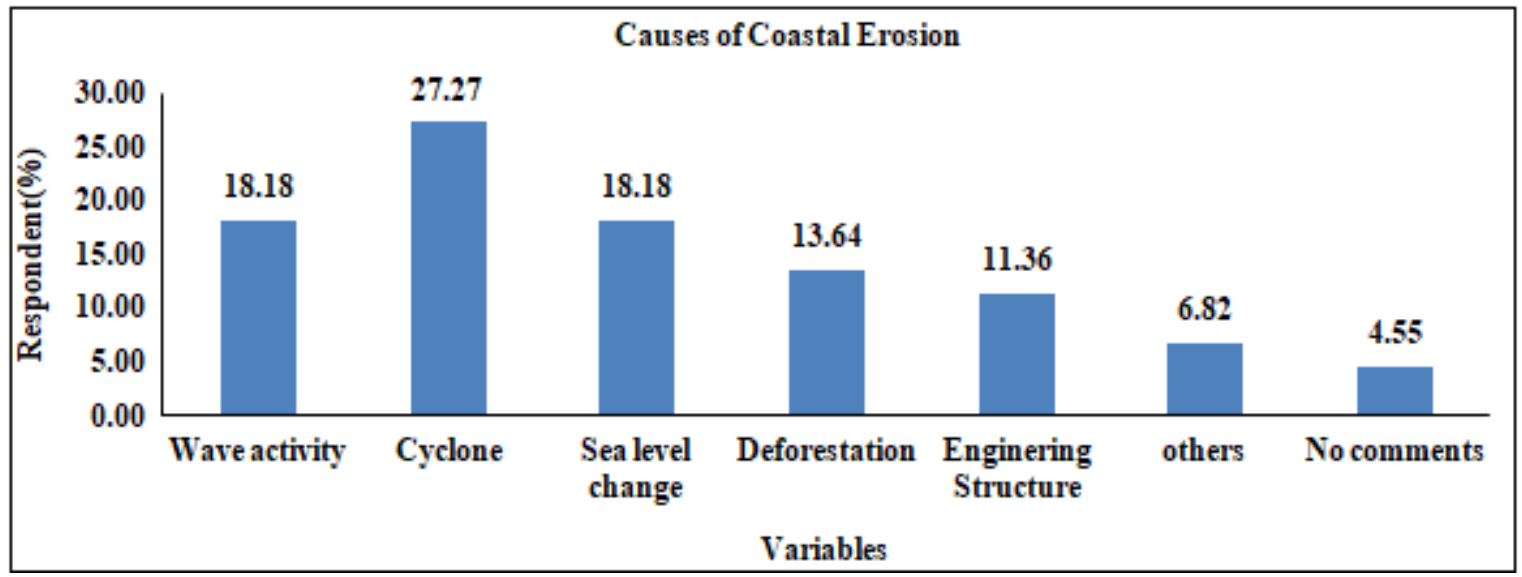

Figure 2: Causes of Coastal Erosion

\subsection{Natural Causes}

\section{1) Tide/Wave activity}

The phenomena of tide and wave are very significant facts in the coastal area. The origin of the tides is in the ocean/sea but the tidal effects travel up estuarine rivers (Rasulpur river, Soulakhal, Dighakhal, Ramnagarkhal and Subarnarekha river).The Tides have characteristic periodic variation; two such periodic variations are easily seen in lunar semi-diurnal tides and lunar fortnightly tides, there are also other short and long period tides. The mean range of the tide during spring at Digha is $4.20 \mathrm{~m}$. In the Contai coastal zone, there are some channels and creeks connected with the sea which have virtually no basin flow throughout the year. So naturally the water level is conditioned throughout the year by tidal flow (Jatranala) - the level of water rises with the flood tide when the maximum erosion is done and falls with the ebb tide. During the cyclonic situations in the coast of Contai region, maximum erosion and damages are occurred along the coastal beaches, estuaries and the creeks.

\section{2) Cyclone}

Cyclonic disturbances along the Contai coast are found maximum in August - September months. The destructive power of revolving tropical cyclones with strong south-west monsoon winds hit the Contai coastal tract frequently during the mid-rainy season. In this period the joint hazards of winds (8-170 km/hour), waves (4.5 m. heights) and tides (rises up to 5-6 m.) cause greatest erosion in a single season. So far as we got the record from the coastal zone research unit it is known that, high erosion prevails in Junput with a rate of $10 \mathrm{~m} /$ per year (S. Mishra, 2004).

\section{3) Sea Level Change}

Rise of Sea level (Due to global warming, environmental pollutions, Wetland capture etc.) is also affecting such severe erosion in the coastal Tract of Contai, West Bengal. This uprising sea level is allowing the bay waves to break closer in shore at present along Junput-Digha beach zones. This is more active in the region of old Digha township area and also in the Bay of Sea-hawk hotel region, but it is less near the Subarnarekha confluence zone.

\section{A. Anthropogenic Causes}

\section{1) Erosion due to Engineering Structure:}

Contai coast of West Bengal is partially protected by boulder paved sea walls to prevent the erosion. Erosion is being occurred in the down ward side of man-made structural zone and in this side the beach area is gradually sinking (12 cm/year) along Digha beach zone (Irrigation Department, Contai). A long boulder wall has been built in Digha where a strong long shore movement of materials is observed and which interfere with this transport. It is also a cause of coastal erosion. 


\section{2) Deforestation}

Vegetation of Digha has already been destroyed due to huge constructions and other anthropogenic activities. Global warming and climatic changes has direct impact on coastal vegetation. Several human interferences (industrialization, pollution, waste disposal, harbours, roads, sand mining, seafacing, commercial or social forestry, construction of resorts and beach tourism) cause destabilization of coastal sand dune and severely influence the dune ecosystem. In these places, the vegetation itself is the target of exploitation. It is the source of fuel-wood and charcoal. Some coastal species were once harvested for their valuable woods (Casuarinaequisitifolia etc.).

Others causes are tourism activity, fishing activity, from natural wetland individual wetland etc.

\section{B. Consequences of coastal erosion:-}

The consequences of the coastal erosion are discussed in three parts, these are as follows: displacement, loss of assets, and loss of livelihoods.

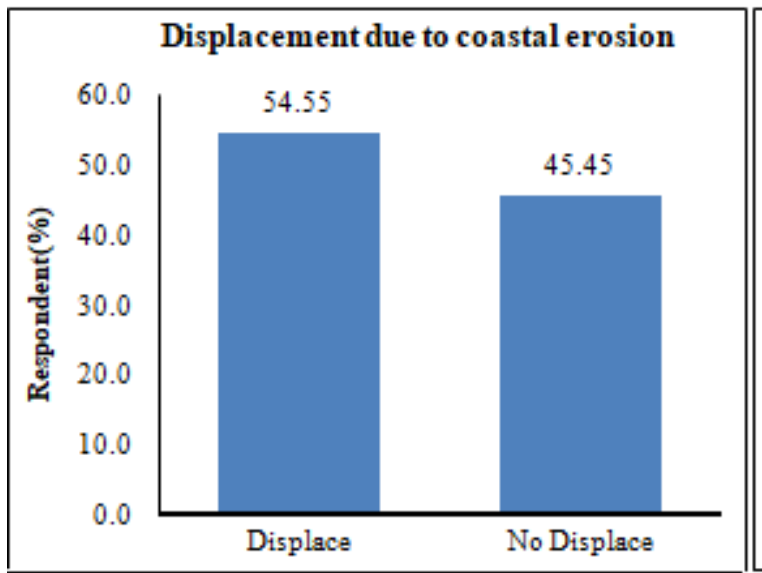

Figure 3: Displacement due to Coastal erosion

Table 5: Type of Displacement

\begin{tabular}{|l|c|c|}
\hline Variable & No. of Respondent & Percent (\%) \\
\hline Retreat & 16 & 66.67 \\
\hline Relocate & 08 & 33.33 \\
\hline Total & 24 & 100 \\
\hline
\end{tabular}

Due to coastal erosion, around 54.5 percent respondents said that they are displaced because of the coastal erosion. Out of this 55\% majority of them are displaced because of the loss of their residential land/homes and rest of others remained at the same place because they have lost only their agricultural land. People started to move out of Gangadharpur, Junput, Bakiput etc, after erosion had hit the villages severely. The bar chart above shows the displaced population of the study area, $66.67 \%$ have retreated, and $33.33 \%$ have relocated to others places after complete loss of land. Many neighboring villages are also affected by erosion.

\section{2) Loss of Assets}

Contai coastal belt had agricultural land as it was one of the principal livelihood options, but with the loss of land agriculture was lost. Land has other values also; it can be used as an investment, a security for a loan or as a capital asset in times of need. The graph below shows the amount

\section{1) Displacement due to erosion-}

The forefathers of some of the villagers settled in Gangadharpur after they had lost their land in Beerkul (Old name of Digha) almost half a century ago. They had settled down acquired land as earlier Gangadharpur was located a few kms away from the shore, they felt safe. RatanMajhi, who is almost 68 years old recalls that he had to wake up very early in the morning and walk almost a mile to reach the shore and start fishing. Relocation is a strenuous activity, but earlier with lesser population and empty spaces available in rural areas people had the option to acquire larger area of land. But with population pressure the numbers of households have increased, now relocation is a problem due to lack of land.

Table 4: Displacement due to Coastal erosion

\begin{tabular}{|c|c|c|}
\hline Variable & No. of Respondent & Percent (\%) \\
\hline Displaced & 24 & 54.55 \\
\hline No Displaced & 20 & 45.45 \\
\hline Total & 44 & 100.00 \\
\hline
\end{tabular}

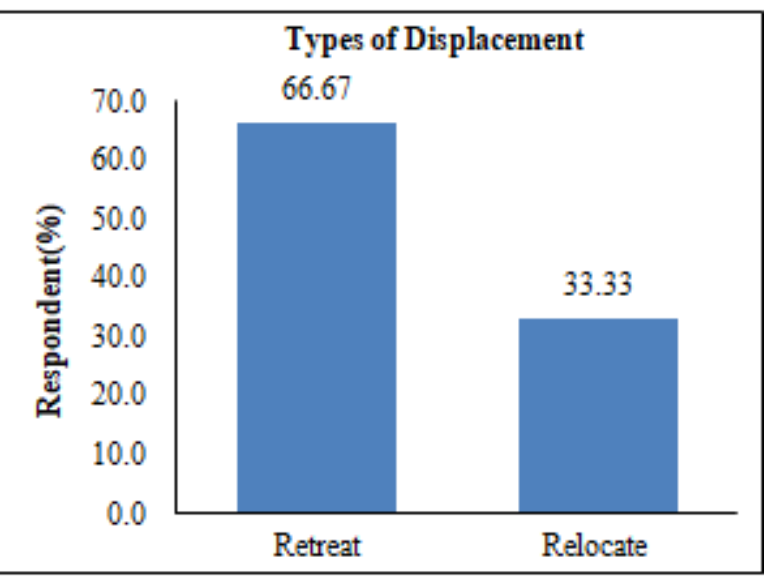

Figure 4: Type of Displacement

of agricultural land lost by the displaced population. The other remaining population also lost their agricultural land.

Table 6: Lost land due to coastal erosion

\begin{tabular}{|c|c|c|}
\hline $\begin{array}{c}\text { Amount of Land } \\
\text { Loss (Decimal) }\end{array}$ & No. of Respondent & Percent (\%) \\
\hline$<50$ & 18 & 40.91 \\
\hline $50-100$ & 12 & 27.27 \\
\hline $100-150$ & 09 & 20.45 \\
\hline $150<$ & 05 & 11.36 \\
\hline Total & 44 & 100.00 \\
\hline
\end{tabular}

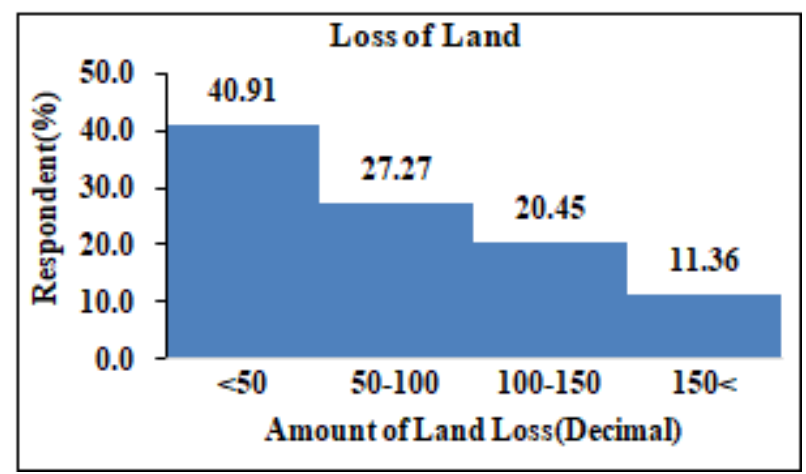

Figure 5: Loss of Land 


\section{3) Livelihoods}

The occupational structure of the displaced population has undergone a major change. Majority of residents are involved in primary activities, i.e. fishing and agriculture. With the loss of agricultural land the people who were depended on such income source had to look for another alternative. Contai coastal belt had large paddy fields, is not fertile enough. Fishing is still popular, but in different forms. Fish culture and dry fish business are the new attractions; traditional method of capturing fish is losing its stand. There were quite a number of reasons enlisted by the respondents for such a kind of shift, like: decreasing marine fish catch, dominance of mechanized boats and trawlers, high maintenance and capital intensive but low returns, unstable and volatile income, high risk investment and many more.

\section{Management}

Government and Non-Governmental agencies have taken some strategies/measures for prevention of coastal erosion. These are as follows:

Table 7: Aid and assistance received from Govt.

\begin{tabular}{|c|c|c|}
\hline Assistance received & No. of Respondents & Percent (\%) \\
\hline Yes & 29 & 65.91 \\
\hline Total & 44 & 100.00 \\
\hline
\end{tabular}

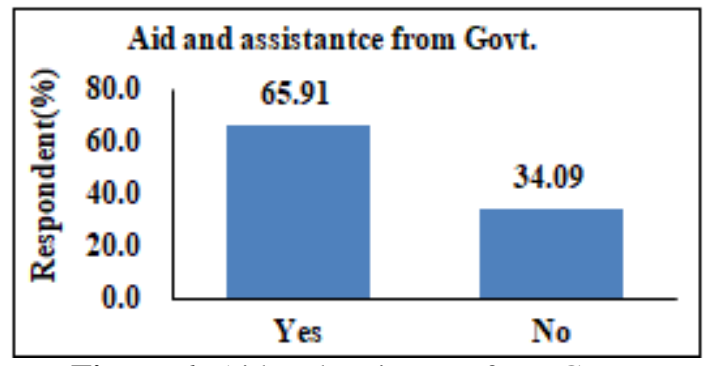

Figure 6: Aid and assistance from Govt.

\section{1) Patta Distribution}

The majority of the population is yet to receive 'Patta' (distribution of government owned land among the poor people by the government free of cost) from the government even after a very long period of displacement. The families which have received the 'Patta' have not received it for the entire entitled amount. No special mode of compensation was formulated after the loss. One of the major implications of landlessness is the dearth of sense of security and economic strength in the times of crisis. This situation is even worse for the displaced people who were land owners and now are landless.

\section{2) Construction of Embankment:}

Government has to ensure better embankments to reduce threats to erosion in the near future. Currently an extension of the sea wall is under progress (Irrigation Dept. WB) to protect the beach and the Contai coastline from further effects of coastline erosion. Few years back an embankment was constructed by govt. from Old Digha to New Digha with the help of rocky boulders.
Table 8: Resident's satisfaction level regarding construction of the embankment

\begin{tabular}{|c|c|c|}
\hline Response & No of Household & Household (\%) \\
\hline No Comment & 4 & 9.09 \\
\hline Yes & 7 & 15.91 \\
\hline No & 33 & 75 \\
\hline Total & 44 & 100 \\
\hline
\end{tabular}

We tried to find out the satisfaction level of locals regarding the construction of embankment work to prevent coastal erosion. Among them 15.91\% replied affirmatively and 75\% replied in the negative and the rest of them made no comment $(9.09 \%)$.

Then, I asked the positive respondents which agency had built the embankments. They gave different answers. They said that $28.57 \%$ of the embankment had been built bu the State Irrigation Department, $14.29 \%$ by NGO and $14.29 \%$ by Panchayat. They were not sure of the rest $42.86 \%$ embankment.

Table 9: Foundation of Embankments

\begin{tabular}{|c|c|c|}
\hline Variables & No. of Respondents & Percent (\%) \\
\hline The State Irrigation Dept. & 2 & 28.57 \\
\hline NGO & 1 & 14.29 \\
\hline Panchayat & 1 & 14.29 \\
\hline Note sure & 3 & 42.86 \\
\hline Total & 7 & 100.00 \\
\hline
\end{tabular}

Embankments constructed to prevent coastal erosion

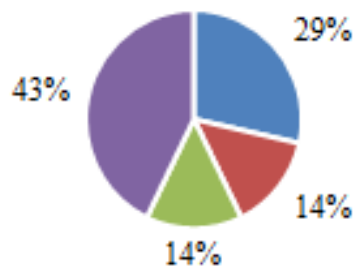

The State Irrigation Dept $=$ NGO " Panchayat " Note sure

Figure 7: Foundation of embankments

\section{3) Afforestation}

Coastal ecosystem is a complex issue and demands regular monitoring and in-depth study because of its fragile nature. Natural calamities such as tsunami, frequent depression, etc. adversely affect the socio-economic situation of this region. Many under-privileged people are dependent on wild plant resources, particularly medicinal uses is remarkable. Many plants particularly Casuarinaequisetifolia is an effective storm resistant tree. A few plant trees are found to be rare, such as Swieteniamacrophylla, Gliricidiasepium, Coccolobauvifera, etc. Further, afforestation programme and conservation measure are very necessary. Afforestation prevents coastal erosion by wind and sea and is mainly found in the western part of the 372.77 hectors.

Regarding the afforestation, 25\% respondents answered that it had been held by the Panchayat. Around $11.36 \%$ replied that it had been done by the State Forest Dept. About $31.82 \%$ respondents replied that it had been a collective effort by the Villagers. On the other hand, $18.18 \%$ respondents were not sure of it and the rest (13.64\%) made no comment. 
Table 10: Afforestation Programme

\begin{tabular}{|c|c|c|}
\hline Variables & No. of Households & Percent (\%) \\
\hline No Comment & 6 & 13.64 \\
\hline Panchayat & 11 & 25.00 \\
\hline The State Forest Deptt. & 5 & 11.36 \\
\hline Collective effort by the villagers & 14 & 31.82 \\
\hline Note sure & 8 & 18.18 \\
\hline Total & 44 & 100.00 \\
\hline
\end{tabular}

\section{Suggestions}

Keeping in mind the above findings/problems, some suggestions are recommended for the development of this area along with an assessment of the resource potentialities for the economic revitalization of the area. These are as follows:

1) Regular maintenance of embankments is a must. Embankments should be repaired much ahead of rainy season. Ad hoc measures need to be curtailed as far as possible. Strict engineering norms must be followed at construction phase. As embankments often collapse due to faulty engineering methods

2) Mangrove regeneration can be encouraged towards Odisha border and spill basin areas. To check the dieback of the mangroves of this area, the first step should be taken by upholding the importance of the mangrove to the school going children and local people. Secondly its importance should be circulated in public meetings. Thirdly distribution of leaf-lets, audio visual display can also be taken up as mode of popularizing mangrove plantation among the local people.

3) Forestry should be increased not only along the shoreline but also in the open lands of inland sights. It is effective for protection from coastal erosion and storm attack and for ecological balance.

4) Maintain the CRZ rules proposed by the Government of India.

5) The running of the cars on the beaches should be banned for prevention of coastal erosion.

6) Forecasting of cyclone should be made for this area to minimize the damage to resources and lives. Some rescue centers must be built in such hazardous zone to give quick shelter to the victims. Delineation of coastal buffer zone is to be completed and a quick communication system is also to be made to connect safe and buffer zone

7) During the cyclone, the govt. should take necessary steps to rescue to vulnerable men. Also they should build houses for homeless people.

\section{Conclusion}

Therefore, on the basis of the above analysis it can be stated that management of coastal erosion is one of the most complicated and difficult tasks that involves integration and planning of several activities in a co-ordinated manner and thereby helping in sustaining the natural resources and the long-term economic growth of our study area. The coastal areas exhibit a variety of specialized ecosystems, some of which are land based and some of them are inter tidal in nature. In the land part of coastal area, terrestrial activities are predominant and they have tremendous impact on the quality of coastal erosion and play a vital role in the development of natural resources. Unless land-based and sea-based activities arc properly integrated and the activities are made compatible to each other, the goal of sustainable development is difficult to attain.

\section{References}

[1] Dey, S., Ghosh, P. and Nayak, A.[2005]: The Influence of Natural Environment upon the Evolution of Sand dunes in Tropical Environment along Medinipur Coastal Area, India, Indonesian Journal of Geography.

[2] Goldewijk, K. K. \& Ramankutty N. [2004]: Land cover change over the last three centuries due to human activities: The availability of new global data sets.GeoJournal, Netherlands.

[3] Gupta, A [1970]. The West Bengal Coast: Its nature and evolution In: AB. Chatterjee, A Gupta and P.K. Mukhopadhyuay (Ed.) West Bengal'. The Geographical Institute, Presidency College, Calcutta.

[4] Jana A and Bhattacharya, A.K. (2012): Assessment of Coastal Erosion Vulnerability around Midnapur Balasore Coast, Eastern India Using Integrated Remote Sensing and GIS Techniques. Journal of the Indian Society of Remote Sensing.

[5] Niyogl. D. [1970]: Geological background of beach erosion at Digha, West Bengal. Bulletin, Geology MinIng and Metallurgical Society, India.

[6] Noujas V and Thomas K V. Erosion Hotspots along Southwest Coast of India. (2015) Aquatic Procedia4 (2015).

[7] O'Malley, L.S.S. [1911]: Bengal District Gazetteers: Midnapore. Government of West Bengal.Calcutta.

[8] Paul, A. K. ( 2002, Coastal Geomorphology and Environment: Sundarban Coastal Plain, Kanthi Coastal Plain and Subarnarekha Delta Plain, ACB Publication, Kolkata,

[9] Pethik, J. [1984]:An Introduction to Coastal Geomorphology. Edward Arnold. London.

[10] Tala S (2020), Changing Land Use / Land Cover Analysis in Contai (Kanthi) Coastal Belt, West Bengal and Odisha, International Journal of Science and Research (IJSR). 